\title{
A política de assistência à saúde no Brasil nos trilhos da história
}

\section{Healthcare policy in Brazil on the path of history}

\author{
Ialê Falleiros \\ Professora-pesquisadora da Escola Politécnica de Saúde Joaquim Venâncio/ \\ Fundação Oswaldo Cruz \\ Avenida Brasil, 4365/322 \\ 21040-900 - Rio de Janeiro - RJ - Brasil \\ iale@fiocruz.br
}

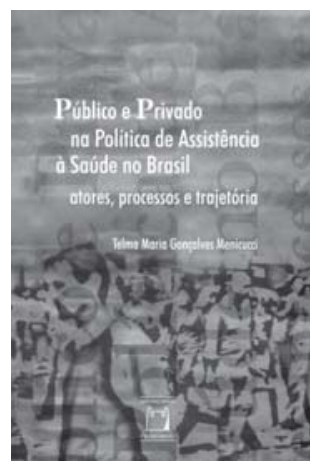

Menicucci, Telma Maria Gonçalves. Público e privado na política de assistência à saúde no Brasil: atores, processos e trajetória. Rio de Janeiro: Editora Fiocruz, 2007. 320p.
A publicação da tese de doutorado de Telma Menicucci é emblemática do momento em que se comemoram os vinte anos de inscrição do Sistema Único de Saúde (SUS) na 'Constituição Cidadã'. Comemorar aqui assume o sentido de 'lembrar junto', construir significados acerca do que é passado, passou por nós e deixou marcas profundas, significados que se moldam a outros elementos que também passaram, como caravanas que deixam pelo caminho rastros, vestígos, cacos, mapas para os que vêm depois e reconstróem suas próprias histórias a partir deles.

É preciso registrar, antes de tudo, a generosidade com que a autora nos apresenta os resultados de sua pesquisa, ancorada em consistente referência bibliográfica e documental. É notável a preocupação em delimitar teórica e metodologicamente suas reflexões e, ao mesmo tempo, sintetizar, a cada item, a cada capítulo, as principais ideias trabalhadas e as principais conclusões a que chegou. Isso torna o texto perfeitamente inteligível para os leitores menos especializados e captura o leitor para a árdua tarefa, entremeada nas mais de trezentas páginas, de compreensão de um processo relativamente recente em nossa história (mas com raízes profundas) a partir de múltiplas variáveis.

Ainda na bibliografia e nos documentos consultados, chama a atenção a forte presença de autores e atores identificados com o projeto liberal (e privatista) de sociedade. Isso é um grande mérito do trabalho, pois expressa a densidade com que a autora nos apresenta os sujeitos políticos coletivos representantes do empresariado da saúde e suas (re)composições nas diversas conjunturas analisadas.

No primeiro capítulo, Menicucci apresenta seu referencial teórico-metodológico: a abordagem histórico-institucional. Ela explicita como desenvolve a investigação da trajetória das políticas de assistência à saúde no Brasil - entendidas como instituições no sentido amplo - e de suas influências na reconfiguração política contemporânea. Nesse sentido, o segundo capítulo trata da política definida nos anos 1960 e suas implicações futuras no que tange a assistência à saúde, enquanto que o terceiro capítulo discute a dinâmica do setor privado dos anos de 1960 aos dias atuais. No quarto capítulo, a autora investiga o 
desenvolvimento das propostas da reforma sanitária, à luz da reflexão sobre seus elementos de ruptura e de continuidade com relação à trajetória institucional no campo da saúde. $\mathrm{O}$ quinto capítulo é dedicado à análise do surgimento da Agência Nacional de Saúde (ANS) e de seu papel na consolidação da dualidade do sistema de assistência à saúde no Brasil. Por fim, propõe-se a autora, nas conclusões, a elaborar uma síntese e apresentar uma explicação plausível para as contradições presentes na política de saúde brasileira.

Em 2008, o redesenho das forças políticas no campo da saúde, ocorrido entre o período de maior expressão do movimento sanitário e os dias atuais, tornou-se alvo de discussão de inúmeros grupos ligados às questões de saúde no Brasil. O assunto desenvolvido nesse livro é, portanto, de amplo interesse dos brasileiros e de especial importância aos que vêm empreendendo esforços de análise das políticas de saúde no país, nos anos 1990 e 2000.

Demarcada constitucionalmente nos princípios e diretrizes do SUS por obra dos movimentos, entidades e partidos defensores da reforma sanitária, a política de saúde pública, universal, integral e descentralizada foi contrastada pelo conjunto das políticas neoliberais que se impuseram na década de 1990 no Brasil, fortalecedor do sistema dual de saúde - público (para os que não podem pagar, para os que não têm emprego formal) e privado (para os que podem pagar e para os que têm convênio-empresa pago pelo empregador), que todos vemos em curso. Telma Menicucci, contudo, considera que esse sistema segmentado não pode ser visto como simples resposta às pressões e mudanças geradas na conjuntura nacional e internacional, ainda que estas favoreçam o aprofundamento da dualidade do sistema de saúde brasileiro. O pulo do gato na compreensão desse quadro é justamente questionar as profundas determinações dessa política ao longo de nossa história, caracterizada pelo dualismo que espelha as desigualdades sociais a que estamos submetidos desde as origens do Brasil e que se manifesta na política de assistência à saúde mais diretamente desde os anos de 1960, quando o modelo previdenciário individual, assistencialista, centrado no atendimento hospitalar, se expande no país. É o esforço hercúleo de compreender as marcas desse processo deixadas para as décadas seguintes que faz desse livro um candeeiro para os que estão fazendo o balanço do SUS e investigando as contradições que as políticas de saúde encerram nas últimas décadas.

A institucionalização do SUS é captada como uma ruptura possibilitada pelo aproveitamento, por parte do movimento sanitário, da 'janela aberta' pelo contexto político de luta pela democracia e de crise do modelo de saúde anterior. Essa ruptura, contudo, não significou nova rota para a assistência à saúde, uma vez que manteve a dupla trajetória pública e privada -, esta última não regulamentada, dando liberdade para os empresários da saúde continuarem seu amplo desenvolvimento e chegar, ao final dos anos 1990, legitimada pela ANS.

A pesquisa fundamenta os principais elementos reforçadores do modelo dual preexistente no ataque indireto e sistêmico ao SUS por parte das forças políticas e econômicas privatizantes, afinadas aos interesses do empresariado da saúde e às restrições das políticas sociais, entre os quais a falta de regularidade do financiamento das ações de saúde; a nãoampliação da capacidade de gasto do governo; e o reforço a uma identidade corporativa entre os trabalhadores e particularizadora das demandas de saúde. 
A reforma do Estado, marcada pela ênfase no seu papel regulatório em substituição à intervenção direta, fomentou a criação das agências reguladoras pautadas nos ideais de eficiência e independência. O surgimento da ANS se deu nesse contexto, passando a conviver com outros instrumentos regulatórios governamentais. A autora nos oferece uma rica discussão dessa política regulatória para o sistema privado, como parte da política de saúde que aprofunda e legitima a segmentação da assistência à saúde no país.

Certamente, esse olhar só foi possível a partir de um distanciamento temporal dos anos 1980. A opção da autora pela perspectiva histórica abrangente permite escapar de um senso comum que preconiza tanto visões apaixonadas do SUS quanto visões céticas ante o turbilhão neoliberal, pondo o processo de construção e implementação das políticas públicas de saúde brasileiras dos anos 1980 e 1990 nos trilhos da história e atualizando a necessidade de sua reformulação sob novas bases, para que se possa de fato superar o dualismo existente desde a década de 1960 e aprofundado no final do século XX. Se a revolução sociocultural proposta pelo movimento sanitário não ocorreu no Brasil dos anos 1980 - a despeito de tanta esperança e luta - e nos anos 1990 cresceu no país uma geração inebriada pelo ideário neoliberal, o início do século XXI já permite um olhar mais atento e contextualizado sobre esse ideário, suas repercussões e consequências históricas, lançando luzes para proposições e ações mais certeiras no longo e difícil processo de construção de um Estado promotor de políticas públicas, universais, gratuitas e com vistas não ao lucro de poucos, mas sim ao bem-estar geral.

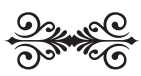

